\title{
Sustainability Factors and Performance
}

\author{
Assa Amiril1, Abdul Hadi Nawawi2, \\ Roshana Takim³ ${ }^{3}$ Siti Nur Farhana Ab. Latif4 \\ ${ }^{1}$ Centre of Postgraduate Studies, ${ }^{2}$ Centre of Estate Management \\ ${ }^{3}$ Centre of Construction Management \\ ${ }^{4}$ Centre of Estate Management \\ Faculty of Architecture, Planning and Surveying, \\ Universiti Teknologi MARA, Shah Alam, Malaysia \\ assa.amiril@gmail.com, hadinawawi@yahoo.com, \\ takim59@yahoo.co.uk, sitinurfarhana@salam.uitm.edū.my
}

\begin{abstract}
A Transportation infrastructure projects often involve the considerable land use and huge resource that can cause serious impacts to the environment and social dislocation. Hence, implementation of sustainable factors is essential. This paper attempts (1) to review infrastructure project sustainability factor and performance, and (2) to propose a framework of relationship between the sustainability factors and performance for railway projects in Malaysia. The results from the literature show that sustainability factors and performance can be categorized under environment, economic, social, engineering/resource utilization and project management.
\end{abstract}

Keywords: Transportation; infrastructure project; sustainability factors; sustainability performance

eISSN 2398-4279 @ 2018. The Authors. Published for AMER ABRA cE-Bs by e-International Publishing House, Ltd., UK. This is an open-access article under the CC BY-NC-ND license (http://creativecommons.org/licenses/bync-nd/4.0/). Peer-review under responsibility of AMER (Association of Malaysian Environment-Behaviour Researchers), ABRA (Association of Behavioural Researchers on Asians) and cE-Bs (Centre for EnvironmentBehaviour Studies), Faculty of Architecture, Planning \& Surveying, Universiti Teknologi MARA, Malaysia.

DOI: https://doi.org/10.21834/ajqol.v3i9.86 


\subsection{Introduction}

The concept of sustainable infrastructure development has emerged since the Brundtland Report on 1987. The report defines sustainable development "meets the needs of the present without compromising the ability of future generations to meet their own need", (Lim, 2009). According to Huang and Yeh (2008), the importance of sustainable infrastructure development is that it has a significant impact on the environment, economy and society. For instance, disturbance of human life and ecosystem resulted from construction and regeneration of infrastructure project development. Furthermore, infrastructure project development presents numerous challenges such as projects are time consuming, costly, and not always sustainable (Lothe, 2006).

Previous research in the field of sustainability infrastructure development has defined the term sustainability in a number of ways. The United Nations ESCAP (2006) defines sustainable infrastructure as infrastructure in harmony with the continuation of sustainability in the economy and environment by designing and maintaining buildings, structures and other facilities with an eye towards resource conservation over the life of the infrastructure. National Research Council of the National Academies, (2009) has referred infrastructure sustainability as a lifeline system that enables meet the needs of current and future generations through cost-effective, physically resilient, socially equitable and environmentally viable.

Sustainability of infrastructure transportation development is defined through it impacts on the economy, environment for and social benefits; measured by system efficiency and effectiveness (Khalid et al., 2012; Jeon \& Amekudzi, 2005). On the other hand, Amekudzi et al. (2009) expressed sustainability of transportation development as a safe, efficient accessibility and improve economic productivity without negatively impacting the natural environment.

Implementation of sustainable concept in infrastructure projects development is crucial because it has a great impact on surroundings and involves many parties (Bueno et al., 2013; Jeon \& Amekudzi, 2005; Litman, 2007). Nevertheless, current literature study shows that less attention and effort have been done on the sustainable development of the transportation system particularly on railway projects (Adnan, 2012; Naidu, 2008) which may be harder to understand from a sustainability perspective by multiple stakeholders (Dasgupta \& Tam, 2005). This has resulting pollution of the environment, greenhouse gas emissions, fatalities and injuries, biological and ecosystem damage, project delays, poor quality, States. (Lim, 2009; Transportation Research Board of the National Academies, 2005). As for Malaysia, infrastructure projects proposed have often not incorporated sustainable development principle; hence, the result has been project failures and stranded facilities (Naidu, 2008).

The importance of implementation sustainability factors is that it can affect the project sustainability performance (Lim \& Yang, 2007; Transport for New South Wales, 2012; Ugwu \& Haupt, 2007; Vanegas, 2003). Apart of that, sustainability factors also facilitate stakeholders, owners and engineers measuring the progress towards sustainable development by comparing the performance achieved with the intended performance (FIDIC, 2004). Hence, this paper attempts (1) to review transportation infrastructure project sustainability factors and performance, and (2) propose a relationship framework between 
sustainability factors and performance for Malaysia railway infrastructure projects.

\subsection{Literature Review}

In order to meet the need towards sustainable development, sustainability assessment systems have been implemented by the construction industry (Clevenger et al., 2013). Recently, several sustainability infrastructure assessment systems have been developed or are under development to measure the sustainability of infrastructure projects (Clevenger et al., 2013; Lim, 2009). They are usually created by the governmental institution, nongovernmental institution, and sometimes in collaboration with academia. These systems use different techniques for determining sustainability emphasizing different sustainable factors (Martland, 2012).

The New South Wales Transport Division is the Australian governments' institution that has developed a Transport Project Sustainability Framework to ensure that their transportation system is sustainable over time and, environmental and sustainability performance is continually improved. The New South Wales Transport division focuses on the three spheres of sustainability i.e. environmental, social and economic that to be integrated during the project planning, development and delivery. The sustainability factors under environmental category consist of GHG emissions, water, pollution control, noise management, resource management, waste management, material consumption and biodiversity. The social category comprises stakeholders' relationship, communities/public acceptance and heritage conservation while corporate sustainability is under the economic category (Transport for New South Wales, 2012).

On the other hand, INVEST is an assessment system that provides a list of sustainable factors best practices to be incorporated into transportation project (Clevenger et al., 2013; Culp, 2011). INVEST was developed by Federal Highway Administration (FHWA), United States and launched on 2012. The sustainability factors of INVEST is designed to address sustainability throughout the project stages namely; planning stage, project development stage, operation and maintenance stage. The INVEST sustainability factors consist of noise quality, ecology and biodiversity, visual impact, waste management, energy and carbon emissions, erosion and sediment control, flora and fauna, health and safety, life cycle cost, cultural heritage, public access and inter-modality of transport (Culp, 2011).

Lim (2009) in his study has identified 23 critical sustainability factors specific for Australian road infrastructure projects. These are air quality, water quality, noise and vibration, erosion and sediment control, flora and fauna, environmental and social impact assessment, life cycle cost, project risk, cultural heritage, inter-modality of transport, functional performance of physical asset, community involvement and public governance, liaison with client, liaison and collaboration with internal stakeholders, type of contract and project governance, compliance with contract and project specifications, hazardous goods, road user safety, road worker safety, quality control, supply chain management, waste management and recycling. These 23 critical sustainability factors are clustered into ten (10) categories; environmental, economic, social, engineering, community engagement, relationship management, project management, institutional sustainability, health and safety, 
resource utilization and management. According to Lim and Yang (2007), every infrastructure project deliverables stages must be guided by the principles of sustainable development to ensure the project is sustainable.

Apart of that, CEEQUAL is also an assessment system that aims to improve sustainability in infrastructure projects of civil engineering works and public realm project by providing an incentive to the designer, client and contractors to adopt best environmental and social practices (Cartwright, 2008). The sustainability agenda in CEEQUAL Assessment Manual consists of 12 key sustainability factors, namely: land use, project environmental management, ecology and biodiversity, landscape, archaeological and cultural heritage, water issues, use of materials, transport, waste, nuisance to neighbors, energy and community relations (Cartwright, 2008; CEEQUAL Scheme Management Team, 2004).

Table 1: Matrix of sustainability factors of transportation infrastructure projects

\begin{tabular}{|c|c|c|c|c|c|c|}
\hline Theme & Foctarstriteria & $\begin{array}{l}\text { New South } \\
\text { Wales } \\
\text { (2012) }\end{array}$ & $\begin{array}{l}\text { INVEST } \\
\text { (2012) }\end{array}$ & $\lim$ & $\begin{array}{l}\text { CEEQUAL } \\
\text { (2008) }\end{array}$ & $\begin{array}{l}\text { Green } \\
\text { LrTES } \\
\text { (200s) }\end{array}$ \\
\hline \multirow{11}{*}{ Envienment } & Land use / sine seloction & & & & $\sqrt{1}$ & $\sqrt{ }$ \\
\hline & Waver quality & $\checkmark$ & & $\checkmark$ & $\checkmark$ & $\sqrt{ }$ \\
\hline & Arr qualing & & & $\checkmark$ & & \\
\hline & Noise qaality & & $\sqrt{ }$ & $\checkmark$ & & \\
\hline & Ecology \& Biodiversity & $\sqrt{ }$ & $\sqrt{ }$ & & $\sqrt{ }$ & \\
\hline & Vianal iampact & & $\sqrt{ }$ & & $\checkmark$ & \\
\hline & Wrate managemeat & $\checkmark$ & $\sqrt{ }$ & $\checkmark$ & $\checkmark$ & \\
\hline & Energy \& Carbon emissions & r & $\sqrt{ }$ & & $\checkmark$ & $\sqrt{ }$ \\
\hline & Pollutica conter & $\checkmark$ & & & & \\
\hline & Emosica $\&$ Sodinent control & & $\sqrt{ }$ & $\checkmark$ & & \\
\hline & Flora \& Funa & & $\sqrt{ }$ & $\checkmark$ & & \\
\hline \multirow{2}{*}{ Beonomic } & Life cycle coet & $\checkmark$ & $\sqrt{ }$ & 8 & & \\
\hline & Project risk & & & $\gamma$ & & \\
\hline \multirow{6}{*}{ Social } & Cultural heritage & & $\sqrt{ }$ & $\sqrt{1}$ & & \\
\hline & Public acoess & & $\sqrt{ }$ & & & \\
\hline & Health and safety & & $\sqrt{ }$ & $\checkmark$ & & \\
\hline & Stakeholder reintionships & & & $\checkmark$ & $\checkmark$ & \\
\hline & Inter modality of transpont & & $\sqrt{ }$ & $\sqrt{ }$ & $\checkmark$ & \\
\hline & Site access/developenent & & & & $\checkmark$ & \\
\hline \multirow{5}{*}{$\begin{array}{l}\text { Engineering } \\
\text { Resource } \\
\text { velization }\end{array}$} & Muterial type \& availability & & $\sqrt{1}$ & & $\checkmark$ & $\sqrt{ }$ \\
\hline & Cototructability & $\sqrt{ }$ & & & & \\
\hline & Rensability & & $\sqrt{ }$ & $\checkmark$ & $\checkmark$ & \\
\hline & Qualing controlinssermence & & $\sqrt{ }$ & $\checkmark$ & & \\
\hline & $\begin{array}{l}\text { Functionality performunee of } \\
\text { pbysical asses }\end{array}$ & & & $\checkmark$ & $\checkmark$ & \\
\hline \multirow{3}{*}{$\begin{array}{l}\text { Project } \\
\text { adniaistrinoa }\end{array}$} & Type of contrist & & & 8 & $\checkmark$ & \\
\hline & Procuremene nechod & & & & $\checkmark$ & \\
\hline & Projoct risk: & & & $\gamma$ & $\checkmark$ & \\
\hline
\end{tabular}

All of the developed sustainability factors reviewed above generally have a similar aim that is to encourage an organization to include sustainable practices in their company's 
strategy and daily work practices.

Another sustainability assessment system for transportation infrastructure projects is GreenLITES. GreenLITES is a sustainability assessment system aimed to encourage development of no negative environmental effects, little disruption to society, suitability of design, low cost construction or no maintenance highways, provision of safe multimodal means of transportation, a medium for the spreading of information and funding for research (Clevenger et al., 2013; McVoy et al., 2010). It was developed by New York Department of Transportation (NYSDOT) in 2008 to align better sustainability efforts in planning, design, construction, and maintenance operations with long-term needs (McVoy et al., 2010). The sustainability factors of this system are environment, economy, social, sustainable Sites, water quality, material and resources, innovation, energy and atmosphere (Clevenger et al., 2013).

Table 1.0 presents the matrix of sustainability factors of transportation infrastructure projects based on reviewed literature. Generally, the sustainability factors can be categorized under several theme i.e. environment, economic, social, engineering/resource utilization and project administration.

\section{Sustainability performance of infrastructure projects}

Implementation of sustainability factors across the project life cycle phase is a crucial aspect in achieving the goal of sustainable development (Shen et al., 2007). According to Vanegas (2003), the degree of project sustainability performance such as a solution of the problem, a satisfaction of the client's need/objectives, clear term of instruction, etc., is highly influenced by the implementation of sustainability factors. Conventionally, time, quality and cost have long been defined as the basic criteria for measuring construction project performance (Chan \& Chan, 2004). Nevertheless, Ugwu and Haupt (2007) in their research findings show that the implementation of sustainability factors has led to sustainable project performance such as better decision-making, minimize wastage, efficient project delivery, avoid delays as well as minimize constructability related-problems (rework, claim, etc.). Lim (2009) identified that implementation of sustainability factors in road projects can minimize pollution and environmental impacts, community/public acceptance, fit for purpose and quality, minimize maintenance and operation cost, minimization risk, completion on time, protect cultural heritage, safe construction etc.

Moreover, Transport for New South Wales (2012) has also identified the advantages of sustainability factors implementation to their project performance such as safe construction, noise and vibration minimization, air quality and dust suppression, prevention of land contamination and degradation, protection of water quality, reduction of construction materials footprint, minimization of carbon footprints and energy use, minimizing water usage, maximizing rainwater harvesting and re-use and meeting waste management standards.

Table 2.0 presents the matrix of identified sustainability performance of infrastructure projects from the previous studies that related to environmental, economic, social, engineering/resource utilization and project management. 
Amiril, A., et.al. / Asian Journal of Quality of Life (AjQoL), 3(9) Jan / Feb 2018 (p.151-160)

Table 2: Matrix of sustainability performance of infrastructure projects

\begin{tabular}{|c|c|c|c|c|c|}
\hline Theare & Sesusiasidiliy Poformance & $\begin{array}{l}\text { New Soud } \\
\text { Wales } \\
\text { (2012) }\end{array}$ & $\begin{array}{l}\text { Lifs } \\
(2009)\end{array}$ & $\begin{array}{l}\text { Uswu \& } \\
\text { Hsajt (2007) }\end{array}$ & $\begin{array}{l}\text { Veteyis } \\
(2003)\end{array}$ \\
\hline \multirow{11}{*}{ Enitonatent } & 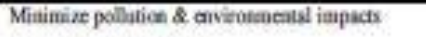 & & $\frac{1}{4}$ & & \\
\hline & A bulansed development & & $\checkmark$ & & \\
\hline & Coanantity/pablic socepsance & & $\checkmark$ & & \\
\hline & Proted nativoloquatic wilaife & & $\gamma$ & & \\
\hline & Mosity uxode msasgeneal sandurts & $\sqrt{ }$ & & & \\
\hline & Maximizing fritrusa harvoding and te-ue & $\sqrt{ }$ & & & \\
\hline & Miniminitg cutba forppins ats enary use & $\sqrt{ }$ & & & \\
\hline & Prolediso of water qualiy & $\sqrt{ }$ & & & \\
\hline & Preveation of lated cotkaninesoen and degrabsion & $\checkmark$ & & & \\
\hline & Ait quality and dust sugpresicon & $\sqrt{ }$ & & & \\
\hline & Noute and vitration ainieniration & $\checkmark$ & & & \\
\hline \multirow{4}{*}{ Ecouonic } & Fil for purpose \& qualiy & & 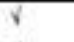 & & \\
\hline & Minimixs mainlenuace \& aperation ós & & $\gamma$ & & \\
\hline & Miatimiratice risk & & $\gamma$ & & \\
\hline & Completion of tine & & $\checkmark$ & & \\
\hline \multirow{10}{*}{ Social } & Proled salural heriluge & & $\gamma$ & & \\
\hline & Save urmel time \& velick opesting oos & & $\checkmark$ & & \\
\hline & Pullic aeseptance & & $\checkmark$ & & \\
\hline & 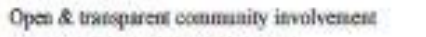 & & $\checkmark$ & & \\
\hline & Pruede interagency eollaburation & & $\gamma$ & & \\
\hline & Safe enestraction & $\sqrt{ }$ & $\checkmark$ & & \\
\hline & Pullic seceptance & & $\checkmark$ & & \\
\hline & Miaimizr hesilh $\&$ sofacy risk. & & $\gamma$ & & \\
\hline & Betla docivien mining & & & $\sqrt{ }$ & \\
\hline & Ces lem of issuructice \& sprroval wistin litse & & & & $\checkmark$ \\
\hline \multirow{9}{*}{$\begin{array}{l}\text { Enginearity } \\
\text { Resouce } \\
\text { ufilixsese }\end{array}$} & Enlancemedh of afrostnachure life span & & $\sqrt{7}$ & & \\
\hline & Actievement of projed objoctives & & $\gamma$ & & \\
\hline & Lotg taving \& ligh quality poducts & & $\checkmark$ & & \\
\hline & Ssvitg maittanabe chis & & $\gamma$ & & \\
\hline & Unituerupled nserixil supply & & $\gamma$ & & \\
\hline & Roludison cos & & $\checkmark$ & $\sqrt{ }$ & \\
\hline & Inctere design imevation & & & $\sqrt{ }$ & \\
\hline & Compittion of tine & & & & \\
\hline & Miaimination wasse & $\sqrt{ }$ & $\checkmark$ & $\sqrt{ }$ & \\
\hline \multirow{3}{*}{$\begin{array}{l}\text { Projed } \\
\text { salmitáuration }\end{array}$} & Coaplation of time & & $\sqrt{ }$ & & \\
\hline & No dispule & & $\gamma$ & & $\gamma$ \\
\hline & Actieves diear's oljectiva & & $\gamma$ & & $\gamma$ \\
\hline
\end{tabular}




\subsection{Methodology}

This study is purely based on the literature review. It reviews the theoretical aspects of research work of sustainability factors and performance in infrastructure projects. The reason of undertaking literature review as the main methodology for the study is to establish the depth and breadth of the current state of sustainability knowledge in the area of sustainable infrastructure development, particularly on transport infrastructure project. Besides, it also helps to establish the conceptual framework for Malaysia sustainable railway infrastructure project to guide the study in subsequent stages.

\subsection{Findings and Discussions}

\section{Propose research framework}

Figure 1 proposes a conceptual framework of the relationship between sustainability factors and performance for railway infrastructure project in Malaysia.

\section{Sustainability Factor}

\section{Environmental}

Land use / site selection, Water quality, Air quality, Noise quality, Ecology \& Biodiversity, Visual impact, Waste management, Energy \& Carbon emissions, Pollution control, Erosion \& Sediment control, Flora \& Fauna

\section{Economic}

Project risk, Life-cycle cost

\section{Social}

Cultural heritage, Public access, Public perception, Health \& safety, Stakeholder relationships, Inter-modality of transport

\section{Sustainability Performance}

Minimize pollution \& environmental impacts; A balanced development; Community/public acceptance; Protect native/aquatic wildlife; maximizing rainwater harvesting and re-use; Minimizing carbon footprints and energy use; protection of water quality; prevention of land contamination and degradation; air quality and dust suppression; Noise and vibration minimization; Meeting waste management standards

Fit for purpose \& quality; Minimize maintenance \& operation cost; Minimization risk; Completion on time
Engineering/Resource utilization Site access/development, Material type \& availability, Constructability, Reusability, Quality control/assurance, Functionality performance of physical asset
Protect cultural heritage; Save travel time \& vehicle operating cost, Safe construction; Public acceptance; Minimize health \& safety risk; Open \& transparent community involvement; Promote interagency collaboration; Better decision making; Clear term of instruction \& approval within time.
Enhancement of infrastructure life span; Increase design innovation; Long-lasting \& high quality products; Saving maintenance cost; Uninterrupted material supply; Minimization waste; Reduction cost; Completion on time; Achievement of project obiectives

Completion on time; No dispute; Achieves client's objectives

Type of contract, Procurement method, Project risk

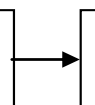

Figure 1: Propose a Conceptual Framework of Relationship between Sustainability Factors and Sustainability Performance for Railway Infrastructure Project in Malaysia. 
This has been developed based on the preliminary literature review. The conceptual framework consists of two major components: Sustainability Factor and Sustainability Performance. The first component is sustainability factors. Drawing from the literature review, there are 27 sustainability factors specific to transportation infrastructure projects have been identified, compiled and distributed under five categories. These sustainability factors embrace the issues of environmental concerns, economic empowerment, social needs, Engineering/Resource utilization and Project Administration.

The second component is the sustainability performance. For each category of the transport sustainability factors, the sustainability project performance also has been identified. These components demonstrate the influence of implemented sustainability factors to sustainability performance in infrastructure projects. Vanegas (2003) articulates that, it is important to incorporate sustainability factors because it contributes in different ways of sustainability project performance. Hence, given the above, these two components (i.e. sustainability factor and sustainability performance) are crucial in the development of a sustainability performance guideline of railway infrastructure projects. The purposes of this framework are to help to see clearly the variables of the study and as a general framework for data collection and analysis.

\subsection{Conclusion}

This paper attempts to review, synthesize and developed an integrated framework of the relationship between Sustainability Factors and Sustainability Performance for Railway Infrastructure Project in Malaysia based on the experience learned from various researchers, the governmental and non-governmental institution of different countries. There are 27 sustainability factors specific to transportation infrastructure projects have been identified that embrace the issues of environmental, economic, social, engineering/resource utilization and project administration. The reviews also show that the influence of implementation sustainability factors to project performance such as minimize pollution, minimize maintenance, reduce operational cost, safe construction, etc.

According to Joumard and Nicolas (2010), the advantage of these sustainability factors is to provide data for managing the construction project (evaluation, performance, control). Therefore, it is necessary that users should understand the assumption, perspective and limitation when using the sustainability factors (Litman, 2007). The outcomes of the study should be useful to promote the sustainability strategies implementation, particularly in Malaysian railway project. In considering these variables, a further empirical research is needed. A combined approach of two methodologies (e.g. qualitative case-study and quantitative survey data) would be useful for data collection prior further validation processes. The outcomes of the research study would provide insight into the Malaysian infrastructure project development and will offer a guideline especially to the railway infrastructure project stakeholders in Malaysia that are looking forward to enhancing sustainability performance of railway infrastructure projects. 


\section{Acknowledgement}

The author would like to acknowledge the contribution of Research Management Institute (RMI), Universiti Teknologi MARA (UiTM) and Ministry of Education (MOE) through supporting the research with Research Acculturation Grant Scheme (RAGS).

\section{References}

Adnan, A. (2012). Sustainable Development of the Rail System: The Case of Malaysia.

Amekudzi, A. a., Jotin Khisty, C., \& Khayesi, M. (2009). Using the sustainability footprint model to assess development impacts of transportation systems. Transportation Research Part A: Policy and Practice, 43(4), 339348. doi:10.1016/j.tra.2008.11.002

Bueno, B. P. C., Vassallo, J. M., \& Cheung, K. (2013). Road Infrastructure Design for Optimizing Sustainability Literature Review. Madrid, Spain.

Cartwright, C. (2008). CEEQUAL The Civil Engineering Environmental Quality and. Atkins Global.

CEEQUAL Scheme Management Team at CIRIA. (2004). An Introduction to CEEQUAL : The Assessment and Awards Scheme for Improving Sustainability in Civil Engineering and the Public Realm. CEEQUAL. London.

Chan, A. P. C., \& Chan, A. P. L. (2004). Key performance indicators for measuring construction success. Benchmarking: An International Journal, 11(2), 203-221. doi:10.1108/14635770410532624

Clevenger, C., Ozbek, M., \& Simpson, S. (2013). Review of Sustainability Rating Systems used for Infrastructure Projects. In 49th ASC Annual International Conference Proceedings. Associated school of construction.

Council, L. (2012). Rail infrastructure projects costing in New South Wales.

Culp, M. (2011). FHWA 's Sustainable Highways Initiative and Self-Evaluation Tool. In APWA Sustainability Conference (pp. 1-16). Portland.

Dasgupta, S., \& Tam, E. (2005). Indicators and framework for assessing sustainable infrastructure. Canadian Journal of Civil Engineering, 32, 30-44. doi:10.1139/L04-101

FIDIC (International Federation of Consulting Engineers) (2004). "Project Sustainability Management Guidelines." Geneva, Switzerland.

Hezri, a a. (2004). Sustainability indicator system and policy processes in Malaysia: a framework for utilization and learning. Journal of environmental management, 73(4), 357-71. doi:10.1016/j.jenvman.2004.07.010

Hezri, A., \& Dovers, S. (2006). Sustainability indicators, policy and governance: issues for ecological economics. Ecological Economics, 60(1), 86-99. doi:10.1016/j.ecolecon.2005.11.019

Huang, R., \& Yeh, C. (2008). Development of an Assessment Framework for Green Highway Construction. Journal of the Chinese Institute of Engineers, 31(4), 573-585.

Joumard, R., \& Nicolas, J.-P. (2010). Transport project assessment methodology within the framework of sustainable development. Ecological Indicators, 10(2), 136-142. doi:10.1016/j.ecolind.2009.04.002 
Khalid, U. A., Bachok, S., \& Ibrahim, M. (2012). Heavy Rail System Route Extension ( Seremban - Sg . Gadut ) and ( Sentul - Batu Caves ): The Case of Greening Trips by Mode Switching from Private Vehicles Trips to KTM Komuter Services. Daegu, South Korea.

Lim, S. K. (2009). Framework and Processes for Enhancing Sustainability Deliverables in Australian Road Infrastructure Projects. Queensland University of Technology.

Lim, S. K., \& Yang, J. (2007). Enhancing Sustainability Deliverables for Infrastructure Project Delivery. In Creating livable, healthy and environmentally viable cities: Asian perspective-Proceedings of the World Sustainable Building Conference 2007 (pp. 467-480). Kowloon, Hong Kong: The Hong Kong Professional Green Building Council (PGBC).

Litman, T. (2007). Developing indicators for comprehensive and sustainable transport planning. Research Record: Journal of the Transportation (pp. 10-15).

Lothe, K. (2006). An Analysis of Constructability Strategies in Project Delivery: Making Infrastructure Construction Sustainable in Copán Ruinas, Honduras. Vasa. Michigan Technological University.

Martland, C. D. (2012). Toward more sustainable infrastructure: project evaluation for planners and engineers. Hoboken, NJ: Wiley.

McVoy, G. R., Nelson, D. A., Krekeler, P., Kolb, E., \& Gritsavage, J. S. (2010). Moving Towards Sustainability: New York State Department of Transportation's GreenLITES Story.

Jeon, M.C., \& Amekudzi, A. (2005). Addressing Sustainability in Transportation Systems: Definitions, Indicators, and Metrics. Journal of Infrastructure Systems, 11(1), 31-50. doi:10.1061/(ASCE)1076-0342(2005)11:1(31)

Naidu, G. (2008). Chapter 7 Infrastructure Development in Malaysia, (March), 204-227.

National Research Council of the National Academies. (2009). Sustainable Critical Infrastructure Systems - A Framework for Meeting 21st Century Imperatives (p.58). Washington, D.C.

Shen, L., Hao, J. L., Tam, V., \& Yao, H. (2007). A checklist for assessing sustainability performance of construction projects. Journal of civil engineering and management, 13(4), 273-281.

Transport for New South Wales. (2012). Transport Projects Division Sustainability Framework : Key performance indicators and targets. New South Wales.

Transportation Research Board of the National Academies. (2005). Integrating Sustainability Into the Transportation Planning Process. In Committee for the Conference on Introducing Sustainability into Surface Transportation Planning (p. 71). Baltimore, Maryland.

Ugwu, O. O., \& Haupt, T. C. (2007). Key performance indicators and assessment methods for infrastructure sustainability-a South African construction industry perspective. Building and Environment, 42(2), 665-680. doi:10.1016/j.buildenv.2005.10.018

Ugwu, O. O., Kumaraswamy, M. M., Wong, a., \& Ng, S. T. (2006). Sustainability appraisal in infrastructure projects (SUSAIP). Automation in Construction, 15(2), 239-251. doi:10.1016/j.autcon.2005.05.006

United Nations ESCAP. (2006). Sustainable Infrastructure in Asia. In Overview and Proceedings Seoul Initiative Policy Forum on Sustainable Infrastructure Seoul, Republic of Korea, 6-8 September 2006 (Vol. 66, p. 218). United Nations ESCAP.

Vanegas, J. a. (2003). Road map and principles for built environment sustainability. Environmental science \& technology, 37(23), 5363-72. 